\title{
Models of Teaching Reading Comprehension Applied by English Teacher of J-2 School In Academic Year 2016/2017
}

\author{
Usadi, Ni Wayan Oktavia \\ English Education Department, Universitas Pendidikan Ganesha \\ oktaoktausadi@gmail.com
}

\begin{abstract}
This research aimed to analyze the models that applied by the English teacher on J-2 SCHOOl. The subject was the English teachers and the students of J-2 in academic year of 2016/2017. This research was designed as descriptive research design. The researcher instruments are observation and interviewThe result of this study is the used of bottom-up and top models in teaching reading comprehension based on Grabe theory. The frequency of directive in first and second meeting the teacher taught with bottom-up model. The teacher used bottom-up model to teach the students with word meaning and the small particle part in reading comprehension. The third until five meeting was top-down model. The teacher would teach the students with a specific aspect, like teach the students about the specific of descriptive text. It could make students more critical about the text. The underlying reasons of English teacher apply models in teaching reading comprehension are to make the process of teaching English can run appropriately with the students level and the students can join the learning process efficiently. Bottom-up and top down model could make the students active and comfortable in the classroom.
\end{abstract}

Keywords: English teacher, teaching models, reading comprehension

\section{Introduction}

English is one of the most widely spoken languages in the world. Learning English is advantageous as it provides us many chances in life. The primary benefit of English is that it bridges us to global business as it is often considered as the language of global business. On the other hand, English has an important role in the word; both developing and developed worlds are growing, for example, Indonesian people use English as their second language after their mother tongue. English is also used as one of the official languages of the United Nations. In fact, we can imagine how big the influence of English language in the current situation. Considering the importance of the language, the Indonesia government has drawn up English as a foreign language that should be mastered by students.

Nowadays, based on the curriculum which is developed by the Indonesia government, the students are expected to master four skills in order to be able to use English communicatively. Among these skills, reading is the fundamental. Anjomshoa \& Zamanian (2014:90) stated that reading is a language-based skill that involves cognitive process. It is the most important skill to be mastered in order to ensure success in learning. According to Murcia (2000) in Nida (2009) said that "Reading is very essential for us in order to increase our knowledge. Even in this modern age and high-teach environments, it is still the most of us rely on our reading ability in order to gain information or expand our knowledge. Pardede (2010), reading is the most crucial skill to master due to several reasons. First, students can usually perform at a higher level in reading than in any other skills. They can quite accurately understand written materials that they could not discuss orally or in writing with equivalent accuracy or thoroughness. Nunan (1999:249) said that "Success in teaching depends on many factors, one of them is teaching models".

In teaching learning activities sometimes, there are factors to affect students' reading English in class. According to the researcher's experience when the researcher practiced become a teacher on Field Development Practice Program (PPL) on November 2016 in SMP Negeri 2 Singaraja, the students of second grade in that Junior High School have difficulty 
when the teacher taught in reading comprehension. Most of the students still have difficulties in reading comprehension because of that the researcher want to know how the teacher taught the students in reading comprehension.

Reading is a process that requires effort on the readers' part if they want to understand what they are reading. Through reading, students' knowledge will automatically be enriched which eventually can influence their language skills, such as speaking, listening, and writing. Mastering the fundamental skill of learning not only can help language learners in learning vocabulary, acquiring basic structures, and improving the necessary linguistic and communication skills, but also help the learners to be in active control of their own learning process. The process of becoming successful at learning creates learners who are autonomous and employ individualized approaches to learning objectives (Soleimani\&Hajghani : 594).

Grobe and Stoller (2002: 9) defined reading as the ability to draw meaning from the printed page and interpret this information appropriately. It means that reading is a process of identifying written or printed text to understand its meaning. Reading helps the reader to construct knowledge, share experiences, feeling, ideas, and develop new perspective. It can be said that reading is a tool for expanding reader's knowledge and helping the readers to communicate with other people. Considering the importance of reading in teaching English, Indonesian government provides sets of a standard competency and basic competency as the minimal requirements that should be achieved by the teacher.

There are several standards that become guidance in conducting teaching and learning process in the classroom in order to reach the goal of education in Indonesia. One of those standards is standard process. Standard process is regulated in Permendikbud no. 65 tahun 2013. According to Permendikbud no. 65 tahun 2013, standard process is the criteria for the implementation of teaching and learning process in basic level and intermediate level of education to reach graduate standard. It means that this standard process will be the guidance to conduct the teaching and learning process in the classroom in order to make the learners able to reach the graduate standard. The teaching and learning process at school should be interactive, inspiring, enjoyable, challenging, and able to motivate the learners to be active participants, and give them opportunity to develop their initiative, creativity, and independence based on their interest and talent.

Based on the statement above, we have to find out about the models applied by the English teachers, especially in the teaching of reading comprehension. According to Aswan et al. (2010) teaching model is a teacher's plan in teaching and learning process to achieve the purpose which he has planned. In other word, teaching models are approaches to teaching students. The teacher has to apply the teaching model to balance the method that the teacher used and the way the teacher applied the learning material. One of the reasons in choosing effective teaching models is to make reading become more interesting and make reading more enjoyable to learn. According to Grabe (2011), the models of teaching reading are bottom-up (traditional view), top-down (cognitive view), interactive model, and metacognitive model. Studying models of teaching reading comprehension is the worth doing because models of teaching plays an important role to the success of students in learning.

The study was conducted in the SPENDUA one of the public junior high school in Singaraja,Bali. The school is a suitable site to the study the model of like teaching reading used by English teachers because the other public schools, SPENDUA over English subject in its curriculum. Based on the researcher's preliminary observation in the school, reading interaction still dominants the teaching of English in the classroom, which confirms the results of previous studies by Nida (2009) and Pardede (2010). Therefore the researcher decided to concted the study in the school, especially in the eighth grade. The eighth grade was focused in the current study become the previous study carried out in the Indonesia EFL 
consist has just investigated the models of teaching reading comprehension at year 2017 of junior high school. It is hoped that by studying the models of teaching reading comprehension in the other year, the current study could give some contribution to the existing literature.

\section{Methods}

The researcher uses descriptive design in this research because this research is focused on a certain phenomenon in the school environment. In this case the phenomenon is the activities of teaching and learning English. This research also does not need to give the treatment to the object of the research. Then, the researcher observes and describes the phenomena as in the fact as clear as possible without manipulation. Therefore, the appropriate design can be used in conducting this research is descriptive research. The design consists of two stages. The first is observation to the teacher and the student. The researcher observes the class the school condition and teaching learning process. The second stage is doing the interview with the English teacher. This interview happens after the researcher doing the observation. In this process the interview the researcher ask detail about the models that they used for teaching.

The study conducted in J-2 SCHOOL. The data obtained during teaching and learning process on English subject. This research method which were namely; observation, recording, note taking, and data transcription. Therefore, the proper insrtument to collect and analyze the data was the reseacher (1) observation sheet, (2) interview guide. The data of this study were analyzed qualitatively by using interactive data analysis model by Miles and Huberman (1994). The several steps in analyzing qualitative data, namely: coding, data reduction, data display, and drawing conclusion.

\section{Finding}

\section{Finding and Discussion}

The observation was done in order to find out the process of teaching reading comprehension which were used by the English teacher at J-2 SCHOOL during the teaching and learning process when the teacher was explaining the material, giving instructions, asking questions and answering the questions. The observations were done in five meetings with different subject matters in each meeting namely, (1) Narrative text, (2) Descriptive text. The observation of those meeting took place at VIII-5, VIII-7, and VIII 9.

The instruments used for observation were observation sheet and mobile phone as audio recorder. In the observation sheet there were two models applied of the English teacher based on Grabe (2011-25) namely (1) bottom-up and (2) top down. Every type of teaching model which was used by the teacher was written down on the observation sheet. Then from this observation sheet, the occurrence of any process of model could be known.

Beside the observation sheet, audio recording was also used to record the voice or conversation produced by the teacher that occurred during the observation of the teaching and learning process when the teacher was explaining the material, giving examples, giving instructions, asking questions, and answering the questions. The recording was done by mobile phone. After that, the record was transcribed into a written form. The transcription can be seen in Appendix.

According to the result of the observation conducted with the English teachers about the models of teaching reading comprehension, there were two teaching models applied by the English teachers. They were bottom-up and top-down models.

Bottom-up is a model of teaching reading by word meaning. The teacher always asks the students about word meaning to transfer the information. Bottom up is a teaching learning process in general aspects. It means that, the students learn the general like descriptive text by 
just mentioning that is descriptive text. This indicates the students learn with small particle aspects. The students comprehend the text by word meaning. The teacher used bottom up model to make students understand the word, sound, letter, sentence, paragraph, and the text as a whole.

Top down is a model of teaching reading comprehension with critical material, get the prior knowledge from the text. This indicates the students read 1 until 2 sentences and then compare them with their experience. Top down model focuses on the meaning of the text. On the other hand, top down also means learn with specific aspects like characteristics, information of the text, and also characteristics of something. In top-down model the students don't read all of the sentences but just read certain vocabularies and phrases to comprehend the meaning of the text.

\section{Discussions}

1) Models in Teaching Reading Comprehension Conducted by Teacher at Eight Grade Students of J-2 SCHOOL in Academic Year 2016/2017

Based on the data presented in the findings, there were two models applied the English teacher of J-2 SCHOOL, according to the Grabe (2011) classification namely bottom-up and top-down model. Top-down is more dominant than bottom-up model. Top down model is more dominant because some of the activity the teacher taught by the background of the information and used the students' prior knowledge. Some examples of each activity pattern are providing to give explanation and illustration about how the models were used in the teaching and learning process at J-2 SCHOOL.

Bottom-up is a model that used by teacher to teach reading by word meaning, sentence, paragraph and text whole. The students will have fun in their learning and it can help the students to have big motivation in reading skill. Top down model is a model used by teacher to teach the students with their background knowledge and their prior knowledge. On the other hand, the teacher teaches the students with specific aspects. This will make the students to learn the kind of text and gain information on the text. Models of teaching reading included how the teacher manage the classroom, make students active, make students critical, understand the material and summarize the material. Those models are representation of traditional and modern models. These two major reading models supported the first and second language learning cognitive processes. They influenced both L1 and L2 reading research and can be distinguished from one another by its focus regarding on how meaning is attained from print. For example, the bottom-up model shows that the reading process is supported by each word in the text and a learner decodes each word to understand the meaning. On the other hand, the top-down model indicates that the reading process is supported mostly by a learner's background knowledge and prior experience.

Discussion of Observation on Teacher 1

Based on the result of models that were used by the teacher, here the writer would like to discuss about models of teaching reading comprehension applied by ELT teacher at J-2 SCHOOL. The writer found that the English teacher applied two models suggested by Grabe $(2011,26)$ such as when the teacher gave the information, told the students to form their group, asked about their understanding, corrected the story, reminding the net meeting and last meeting, word meaning, retell the story. The teacher asked about the word meaning and then the students would learn about the word meaning on the text. According to Ahmadi (2013), the whole reading process is based on the words and learners construct meaning from context by recognizing each word. It means that the teacher will know the context of the story. Based on the meaning the students would arrange work easily. It is good for poor 
reader, because they will learn in the low ability to make them more understand the story. In other words, poor readers put more attempt into recognizing text which leave less processing ability in the brain for reading comprehension. It is bottom-up because the students just mentioned about the last meeting and they already understand about the material. It is bottomup because the students just heard and prepared something they needed for study. It is necessary to do because the teacher needs to make students enjoy, ready, and prepare themselves for the process of teaching so the teacher need to make students ready in the classroom.

\section{Discussion of Observation on Teacher 2}

This part is the discussion on models of teaching reading comprehension applied by ELT teacher 2 at J-2 SCHOOL. From the observation, the writer found that teacher 2 also applied the models of teaching in teaching process even though not all of the models were done effectively but so far it could be said that the teacher succeed in applying the models in the classroom. The steps found on the teaching process were about the information on the story, and the true story. There were the process of top-down asked the students about the example of descriptive text, the purpose of descriptive text, and also the characteristics of things or animal. The teacher hopes the students to be critical about descriptive text. On the other hand, the students also learned about the specific of descriptive text like describing something and animal. By being critical about something it helped to activate the schema. The students automatically identify something about descriptive text like animal, thing on the classroom and home. When the teacher asked about the animal and the characteristics of animal, the students automatically mentioned about the characteristics of animal and also demonstrated what they know about the animal. It is encouraging because by using of characteristics of animal the students can more understand the content of descriptive text. And if someday the students try to make a descriptive text that they will know the mean because they have learnt before. The students would be work in group. When the students form their group, the students started to form their group. This indicates the teacher will set the students activity. The teacher told the students to form their group to make the students busy with the material and discuss the material. It is very good because the students can talk with their friend if they have less understanding about the material. It is apply by the teacher in group, the students divide into some group and the teacher give to the material to translate the text. That text is different topic with every group. After that, the teacher asks to them to presentation in front of the class. The activity in this research are different to the result of the research conducted by Annisa Ahsan (2015), which found that the techniques in teaching reading is KWLH technique. KWLH teachnique was one step 'to make students more active in the classroom. The teacher start with the background of the topic and asks the students to do active thinking. Those activity were used to make the students more fun and active in the classroom..

\section{2) The Result of the Interview about the Models Applied By Teacher in Reading Comprehension at Eight Grade Students of J-2 SCHOOL in Academic Year 2016/2017}

There were four reasons of the teachers about why they used certain models to teach the students in teaching and learning process.

a) The first reason was to develop the students reading skill.

It was because the teacher could develop the students reading skill by using the models. In addition, the teacher used the model of teaching reading because the students will love their reading, so that the students could develop their reading skill. In the learning process the teacher always asks the students about the word meaning, the example, and the 
material based on their prior knowledge. Based on the activities, the students automatically become active in their reading process. The students become more active and more critical about the material, so that the students could develop their reading skill based on new vocabularies.

b) The second reason was to help the students to comprehend the learning material.

It was because sometimes the teacher found difficulties in explaining English concept to the students, so the teacher use bottom-up and top-down models to help the students to comprehend the learning material to avoid the students' misinterpretation. This was because the teacher knows that their students lack of English vocabulary. There was no empirical review related for this research. Sometimes teacher has to choose an effective model to teach, so that the students can be more active in the classroom. So, the teacher used bottom-up and top-down in order to deliver the message and make it easier for the students to catch the point of the material taught by the teacher. Thus, they will understand the material easily and comprehend the concept of certain material which will be long term memory.

c) The third reason was to make a fun and comfortable learning process.

Sometimes the teacher feels it is not easy to make the students feel fun and comfortable in their learning process, it was because the teacher always gave the material without asking about the students' understanding about the material, so the students ignored the material without doing anything. In addition, the teacher used bottom-up and top-down models because by using these models the teacher can teach the students space-by-space mental translation and it could make the students more active in the classroom. On the other hand, the students also learned based on experience in top-down model, the students can be more critical based on their prior information, so the students find their reading process easier. d) The last reason was to help the students understand the material

The used of bottom-up and top-down models by the teacher could make the students felt secure and become more communicative because they were in the comfortable learning situation. It was because the teacher used the model in teaching learning process that suits the level of student's needs. In addition, the used of the model must also tailored to the material to be taught. So, the teacher also would be more selective to choose model while teaching reading because when the students are happy in their learning process they also understand the material.

Further description above, the teacher would teach the students by bottom-up and top down models because with these models the students become more active and enjoy their learning. By using the models, the students have big motivation to learn. To choose a good model for teaching reading was very important, because model could set the students learning and could make a good situation. Besides that, interactions in the classroom are the reward between teacher and students in learning process. The used of bottom-up and top down model was very appropriate for the students' level. It can be seen from the students' response, the students became more active in the classroom, the students could comprehend the material, the students could understand the vocabularies, and the last the students could know the word meaning.

It indicates that the bottom-up and top-down models were applied by the English teachers of J-2 SCHOOL. It was based on the observation and interview with the teachers. Bottom-up and top-down models gave a good impact to the students and make the students became more active in the classroom. So, the situation was very conducive and the students loved their reading. Here are the real data about the bottom-up and top-down model that were applied by teachers of J-2 SCHOOL. It related to the Grabe theories. 
3) The Students' Responses of Using the Models at Eight Grade Students of J-2 SCHOOL in Academic Year 2016/2017

Based on the findings of the study, it was shown that the responses from the students showed that they liked to be taught using models applied by the teachers. The situation in J-2 SCHOOL was very good. It could be seen when the students learn, the students have big motivation to read the text. Choosing the model need to consider the students level, so that the students could have fun and enjoy their learning process. The teacher gave good explanation, so that the students were very active in the classroom. The interaction between teacher and students was very good, so that the students had big motivation to read the text and shared their prior knowledge with their friends.

The used of bottom-up model could help the students learn from space by space mental translation. The bottom-up learners could learn from sounds, words, letters, and the last was sentence. It could make the students learn more with little interference from his/her own background knowledge." (Grabe\&Stoller, 2002, p.32). Additionally, this process that decodes word-by-word causes slow and taking a lot time and effort in reading comprehension because short-term memory is overloaded, and readers forget easily what they have read when reading comes to an end. It can be concluded that readers may only remember words separately without integrating them into a cohesive recognizing.

The used of top-down model refers to a driven model where the students' prior information and expectations help them to construct meaning from a reading text. The topdown learner could learn from the text based on their prior information. On the other hand, top-down learners also learn by their experience. This model makes the students emphasize on reading skills like prediction, and summarizing as well as anticipating from texts. The topdown model process is also called "text sampling" (Cohen, 1990). It means that, it is not necessary a reader to read all of the vocabulary and sentences in the text or read the context, word by word, but rather selects certain vocabularies and phrases to comprehend the meaning of the text and some key words can help the reader to recognize the text quickly.

There were some responses said by the students why they liked their teacher used bottom-up and top-down models in the teaching learning process, they are as follows:

a) The students more understand the content of the English material itself.

The used of effective model made the students more understand the content of the material. So, the use of bottom-up and top-down model helped them to get better understanding with the content in English material. By understanding the material easily, the students were able to conclude the subject matter in each day of their learning process.

b) The students could know various vocabularies.

The use of bottom-up and top-down models facilitated the students in other aspect, which is an English vocabulary. As we know that English vocabularies are complex, so the use of bottom-up a top-down by the teacher would help them to enrich their vocabulary mastery and have long-term memory, so it could be useful for the students when they wanted to practice their English.

c) The students could retell the story in front of the class.

That is the students' response of using bottom-up and top-down models, the students could retell the story in front of the class. The students' could retell the story because the teacher gave the time for students to retell the story and always asks the students about the story. In pre-reading the teacher always asks the students about the story, the moral value, and the students should retell the story based on their own word. Because of using their own word the students automatically become easier to talk in front of the class.

d) The students could answer the meaning of the word. 
The used of bottom-up and top-down models made the students could answer the meaning of the word. Before the teacher asked the students about the meaning of the word the students must be ready with their dictionary. This helped the students to learn and understand the material space by space mental translation. Besides that, the students also must be ready with their prior knowledge. So, the students can be more active in the classroom.

e) The students could identify things based on clue.

By using bottom-up and top down models the students could identify things based on clue. When the teachers identify things, the students already have their prior information. In indicates the students are more active to catch information for their friends, so the classroom can be more conducive and the students become more active.

f) The students could make a descriptive text about things in the classroom or their home with their own word.

The students could make a descriptive text about things in the classroom or their home with their own word. This indicates the students have prior information to make a good descriptive text. The use of bottom-up and top-down facilitated the students in mastering the descriptive rules. So, the use of bottom-up and top-down models by the teachers facilitated them to understand descriptive text easier and apply it into sentences.

\section{Conclusion}

As stated in the previous chapter, the study was conducted to classify the processes of the models that were used by the English teachers of J-2 SCHOOL in the teaching and learning process, the reasons for the English teachers using models of teaching reading comprehension, and the students' responses on the use of models of reading comprehension applied by the English teacher.

Based on the results of the observations and interviews, there were several things that can be concluded.

1. There were two models of teaching reading comprehension applied by the English teachers of J-2 SCHOOL Academic year 2016/2017.

a. Bottom-up model is a model used by teacher for beginner level. Bottom-up model refers to a kind processing in which meaning derived from accurate, sequential processing words. The emphasis is on the general text rather than the reader's background knowledge or language ability.

b. Top down model is a model that used by teacher to make students more critical in the classroom. Top-down model refer to deriving meaning by using one's background knowledge, language ability, and expectations. The emphasis is on the reader rather that the text.

2. Based on the interview results, here are some reasons why the English teacher used bottomup and top-down models in the teaching learning process:

a. The first reason is to develop the students' skill.

b. The second reason is because bottom-up and top down models are appropriate teaching models that can help the students understood the material.

c. The third reason of using bottom-up and top-down models is to help the teacher to create a relaxing situation.

3. From the results of the observations which were distributed to the students who were taught using bottom-up and top-down models, here are the students' responses about the use of bottom-up and top-down models by their teacher.

a. Bottom-up and top-down models were able to facilitate the students in some aspects such us the content of English material, vocabulary, and descriptive text. 
b. Bottom-up and top-down models were able to negotiate social rules in some aspects such as make the relationship between teacher and students. The students could response the teacher such us about meaning of word, retell the story in front of the class, make descriptive text, and identify the think in terms of teaching and learning process.

\section{References}

Aswan et al. (2010). Strategi Belajar Mengajar. Jakarta. Reneka cipta

Cohen, A. D. (1990). Strategies in second language learning: Insight from research. In R. Phillipson, E. Kellerman, L. Selinker, M. S. Smith, \& M. Swain (Eds.), Foreign/Second Language Pedagogy Research. Cleve: Multilingual matters.

Cahyono. (2011). The teaching language skill and English language components. Malang: State university of Malang Press

Channa dkk.(2015). Developing Reading Comprehension through Metacognitive Strategies: A Review of Previous Studies. Muhammadiyah University Of Surakarta

D. R. Reutzel.DKK. (2010). The Relationship of Top Down Reading Theories to WholeWord Reading Instruction. University of Glasgow

Fahmie S.2013.Reading Theory.Universitas Pendidikan Sultan Indris.fitrahilahi.blogspot.co.id/2013/05/reading-theory-html on May 11, 2017

Gede I. (2015). A Study Of Code Switching Used By English Teacher As Communication Strategy In Teaching English As Foreign Language At SMK N 2 Seririt In Academic Year 2014/2015. Ganesha University Of Education

Grabe, W., \& Stoller, F. L. (2002). Teaching and researching reading. Harlow: Pearson Education.

Grabe, W. (1991). Current developments in second language reading research. TESOL Quarterly, 25(3),375-406 